\title{
A report on two follow-up investigations of the Malta-Project
}

\author{
W H JOPLING* \\ 389a Holmesdale Road, South Norwood, London SE25 6PN
}

\section{Introduction}

The objective of the first follow-up investigation, carried out in April 1983, was to examine the multibacillary patients who had been given multidrug therapy (MDT) in Malta since 1972. The particular objectives were the following: 1, to look for signs of clinical relapse; 2 , to discover if any leprosy bacilli, whether solidstaining or granular, were present in skin smears; and 3, to study the incidence of side-effects. ${ }^{1}$ Professor E Freerksen's design of the Malta-Project was to treat by MDT all leprosy patients whose names appeared on the leprosy register at the Ministry of Health, and similarly to treat all new patients diagnosed in subsequent years, with the objective of eradicating the disease from Malta by rapidly rendering the patients non-infectious:

'The Malta-Project is not meant to be a trial with the objective to assess antileprosy drugs, but an eradication programme which is exclusively based on antimycobacterial chemotherapy. ${ }^{2}$

For my part, however, it is as an early and important piece of therapeutic reasearch that I view the Project, and my report does not touch on the eradication aspect.

Two hundred and six patients began MDT in June or July 1972, and included paucibacillary and multibacillary cases. The majority had received monotherapy with dapsone for varying periods measured in years. MDT in all cases consisted of four drugs: rifampicin, dapsone, prothionamide, and isoniazid, the last three being incorporated in a tablet named Isoprodian, and details of dosage and sideeffects are given in Dr Depasquale's paper in this series (pp 00-00). The shortest course was 5 months (a BL patient who had previously received dapsone for 6 years), and the longest was 89 months (a new and hyperactive LL patient).

* WHO short-term consultant 9-30 April 1983, and temporary adviser 1-9 April 1986 


\section{Materials and methods}

There were 128 patients listed as multibacillary who were available for examination in April 1983, 75 males and 53 females, their ages ranging from 20 to 82 years, with a mean of 55 years. Drs E Bonnici and G Depasquale assisted by carrying out some of the clinical examinations, but all skin smears were my responsibility, and I took 6 smears from each of the 128 patients, in the following order:

Smear No. 1 from the right earlobe.

Smear No. 2 from the left earlobe.

Smear No. 3 from the right mid-finger (dorsum of 1 st phalanx).

Smear No. 4 from the left mid-finger (dorsum of 1 st phalanx).

Smear No. 5 from the right upper arm (just above elbow).

Smear No. 6 from the left upper arm (just above elbow).

\section{Results}

Findings in six of the 128 patients were excluded because a study of case records showed that they were paucibacillary throughout. This left a total of 122 multibacillary patients, and from this list a further six were excluded as two had not completed MDT, and four because Dr H Huikeshoven, to whom urine samples were sent for dapsone testing by his ELISA method, ${ }^{3}$ could not give an unequivocal assurance regarding absence of dapsone in their urine specimens. Urine samples from the two patients who had not completed MDT were found to be strongly positive. All other specimens were negative.

This left 116 multibacillary patients for clinical and bacterial follow-up, and they consisted of 70 males and 46 females, their ages ranging from 22 to 82 years with a mean of 56. At the time of diagnosis 88 had been classified as LL, 22 as BL, and 6 as BB.

\section{CLINICAL FINDINGS IN 116 PATIENTS}

No signs of clinical relapse were found.

\section{BACTERIAL FINDINGS IN 116 PATIENTS}

Examination of skin smears was carried out by Dr Marian Ridley at the Hospital for Tropical Diseases, London, and 36 were found to have positive smears (31\%); 26 had only granular bacilli (Table 1), and 10 had a few solid-staining bacilli ('solids') (Table 2). In the 10 patients with 'solids', one or other finger was positive in eight, and in seven the fingers were the only sites containing them (Table 2). It is 
Table 1. Details of 26 multibacillary patients with only granular bacilli in follow-up skin smears in April 1983

\begin{tabular}{|c|c|c|c|c|c|c|}
\hline \multicolumn{2}{|c|}{ Patient } & \multirow{2}{*}{$\begin{array}{l}\text { DDS prior } \\
\text { to MDT } \\
\text { (years) } \\
3\end{array}$} & \multirow{2}{*}{$\begin{array}{l}\text { MDT began } \\
\text { June } 1972\end{array}$} & \multirow{2}{*}{$\begin{array}{c}\text { MDT (months) } \\
56\end{array}$} & \multirow{2}{*}{$\begin{array}{c}\text { Months since } \\
\text { beginning MDT } \\
130\end{array}$} & \multirow{2}{*}{$\begin{array}{c}\text { Months since } \\
\text { ending MDT }\end{array}$} \\
\hline 1 & LL & & & & & \\
\hline 2 & $\mathrm{BL}$ & 7 & June 1972 & 33 & 130 & 97 \\
\hline 3 & LL & 24 & June 1972 & 30 & 130 & 100 \\
\hline 4 & LL & 19 & June 1972 & 29 & 130 & 101 \\
\hline 5 & LL & 11 & June 1972 & 23 & 130 & 107 \\
\hline 6 & LL & 19 & June 1972 & 23 & 130 & 107 \\
\hline 7 & LL & 17 & June 1972 & 22 & 130 & 108 \\
\hline 8 & $\mathrm{LL}$ & 5 & June 1972 & 22 & 130 & 108 \\
\hline 9 & LL & 29 & June 1972 & 21 & 130 & 109 \\
\hline 10 & LL & 20 & June 1972 & 21 & 130 & 109 \\
\hline 11 & $\mathrm{BL}$ & 5 & June 1972 & 20 & 130 & 110 \\
\hline 12 & LL & 19 & June 1972 & 20 & 130 & 110 \\
\hline 13 & $\mathrm{LL}$ & 5 & June 1972 & 20 & 130 & 110 \\
\hline 14 & $\mathrm{LL}$ & 26 & July 1972 & 80 & 129 & 49 \\
\hline 15 & LL & 21 & July 1972 & 26 & 129 & 103 \\
\hline 16 & LL & 14 & July 1972 & 26 & 129 & 103 \\
\hline 17 & LL & 23 & Sept. 1972 & 12 & 127 & 115 \\
\hline 18 & LL & 17 & Nov. 1972 & 17 & 125 & 108 \\
\hline 19 & $\mathrm{LL}$ & 15 & Apr. 1973 & 71 & 120 & 49 \\
\hline 20 & LL & 1 & Feb. 1974 & 48 & 110 & 62 \\
\hline 21 & BL & 0 & July 1974 & 16 & 105 & 89 \\
\hline 22 & LL & 2 & Mar. 1978 & 26 & 61 & 35 \\
\hline 23 & LL & 3 & Aug. 1978 & 21 & 56 & 35 \\
\hline 24 & LL & 0 & June 1979 & 11 & 46 & 35 \\
\hline 25 & LL & 0 & Mar. 1980 & 32 & 37 & 5 \\
\hline 26 & LL & 0 & May 1982 & $\begin{array}{c}8 \\
\text { (interrupted) }\end{array}$ & 11 & 3 \\
\hline
\end{tabular}

$\mathrm{LL}=$ Lepromatous. $\mathrm{BL}=$ Borderline-lepromatous.

possible that these 'solids' represent 'persisters' (drug-sensitive, dormant bacilli), and the generous supply of dermal nerves in fingers increases the likelihood that bacilli sheltering within them may be extracted by the tip of the scalpel blade.

\section{OTHER FINDINGS IN 122 PATIENTS}

Routine urine tests revealed protein in seven and sugar in eight. In addition, one specimen contained protein and sugar. The finding of glycosuria in nine patients reflects the high incidence of diabetes in Malta, and the majority of these nine patients were known diabetics. 
Table 2. Details of 10 multibacillary leprosy patients with solid-staining bacilli ('solids') in follow-up skin smears in April 1983

\begin{tabular}{|c|c|c|c|c|c|}
\hline \multicolumn{2}{|c|}{ Patient } & $\begin{array}{c}\text { MDT } \\
\text { (months) }\end{array}$ & $\begin{array}{l}\text { Months since } \\
\text { beginning MDT }\end{array}$ & $\begin{array}{l}\text { Months since } \\
\text { ending MDT }\end{array}$ & $\begin{array}{c}\text { Findings in skin smears, } \\
\text { April } 1983\end{array}$ \\
\hline 1 & $\mathrm{LL}$ & 74 & 130 & 56 & $\begin{array}{l}\text { A few 'solids' in left arm. } \\
\text { The other } 5 \text { smears are negative. }\end{array}$ \\
\hline 2 & LL & 72 & 121 & 49 & $\begin{array}{l}\text { One 'solid' in right mid-finger. } \\
\text { The other } 5 \text { smears are negative }\end{array}$ \\
\hline 3 & LL & 42 & 83 & 41 & $\begin{array}{l}\text { A few 'solids' in left mid- } \\
\text { finger, and a few granular bacill } \\
\text { in right arm. The other } 4 \\
\text { smears are negative. }\end{array}$ \\
\hline 4 & LL & 41 & 130 & 89 & $\begin{array}{l}\text { A few 'solids' and granular } \\
\text { bacilli in right earlobe and } \\
\text { right mid-finger. The other } \\
4 \text { smears are negative. }\end{array}$ \\
\hline 5 & $\mathrm{BL}$ & 24 & 130 & 106 & $\begin{array}{l}\text { One 'solid' in right mid-finger. } \\
\text { The other } 5 \text { smears are negative. }\end{array}$ \\
\hline 6 & LL & 23 & 130 & 107 & $\begin{array}{l}\text { One 'solid' in right mid-finger. } \\
\text { The other } 5 \text { smears are negative. }\end{array}$ \\
\hline 7 & $\mathrm{BL}$ & 21 & 56 & 35 & $\begin{array}{l}\text { A few 'solids' in left mid- } \\
\text { finger. The other } 5 \text { smears } \\
\text { are negative. }\end{array}$ \\
\hline 8 & BL & 20 & 130 & 110 & $\begin{array}{l}\text { A few 'solids' in left mid- } \\
\text { finger. The other } 5 \text { smears } \\
\text { are negative. }\end{array}$ \\
\hline 9 & $\mathrm{BL}$ & 20 & 94 & 74 & $\begin{array}{l}\text { One 'solid' in left mid-finger. } \\
\text { The other } 5 \text { smears are negative. }\end{array}$ \\
\hline 10 & LL & 14 & 45 & 31 & $\begin{array}{l}\text { A few 'solids' in right arm, and } \\
\text { a few granular bacilli in all } \\
6 \text { smears. }\end{array}$ \\
\hline
\end{tabular}

In patients 1, 4, 5, 6 and 8, MDT replaced dapsone monotherapy.

\section{THE SECOND FOLLOW-UP INVESTIGATION, APRIL 1986}

This involved examining the 10 patients who were found to harbour 'solids' in 1983. No signs of clinical relapse were found, and examination of six skin smears, taken in the same order as in 1983, failed to show bacterial relapse (Table 3). One patient had died, one had no bacilli, five had only granular bacilli, and three had a few 'solids'. Urine was positive for protein in Nos 1, 8 and 10, and sugar was found in No. 5 (a known diabetic). The 'spot test' for dapsone was negative in all.

As regards the 26 patients listed in Table 1, Dr Depasquale informs me that 
Table 3. Follow-up skin smears on patients who had 'solids' in April 1983

\begin{tabular}{|c|c|c|c|c|}
\hline \multicolumn{3}{|c|}{ April 1983} & \multicolumn{2}{|c|}{ April 1986} \\
\hline Patient & $\begin{array}{c}\text { MDT } \\
\text { (months) }\end{array}$ & Findings & $\begin{array}{l}\text { Months since } \\
\text { ending MDT }\end{array}$ & Findings \\
\hline 1 & 74 & Few 's' arm (L) & 92 & No AFB found \\
\hline 2 & 72 & One 's' finger (R) & 85 & $\begin{array}{l}\text { Few 'gr' ear }(\mathrm{R}) \\
\text { \& both fingers }\end{array}$ \\
\hline 3 & 42 & $\begin{array}{l}\text { Few 's' finger (L) } \\
\& \text { few 'gr' arm (R) }\end{array}$ & 77 & Few 'gr' ear (R) \\
\hline 4 & 41 & $\begin{array}{l}\text { Few 's' \& 'gr' ear }(\mathrm{R}) \\
\text { \& finger }(\mathrm{R})\end{array}$ & 125 & $\begin{array}{l}\text { Few 'gr' ear }(\mathrm{R}) \\
\& \text { finger }(\mathrm{L})\end{array}$ \\
\hline 5 & 24 & One 's' finger $(\mathrm{R})$ & 142 & Few 'gr' finger (L) \\
\hline 6 & 23 & One 's' finger (R) & 143 & $\begin{array}{l}\text { Few 'gr' ear (L) } \\
\& \text { finger (L) }\end{array}$ \\
\hline 7 & 21 & Few 's' finger (L) & 71 & Patient died, 68 yrs \\
\hline 8 & 20 & Few 's' finger (L) & 146 & $\begin{array}{l}\text { Few ‘gr' ear (R); } \\
\text { few ‘s' \& 'gr' ear (L) }\end{array}$ \\
\hline 9 & 20 & One 's' finger (L) & 110 & $\begin{array}{l}\text { Few 's' \& 'gr' finger (L); } \\
\text { few 'gr' arm (L) }\end{array}$ \\
\hline 10 & 14 & $\begin{array}{l}\text { Few 'gr' in all 6; } \\
\text { few 's' arm (R) }\end{array}$ & 67 & $\begin{array}{l}\text { Few 'gr' ears \& fingers; } \\
\text { few 's' both ears }\end{array}$ \\
\hline
\end{tabular}

's' = 'solids'. 'gr' = granular bacilli

not one has developed any 'solids' over the past 3 years, and the majority now have negative smears. The most significant finding, however, is that I found no evidence of clinical or bacterial relapse in the group who had 'solids' in 1983.

\section{Discussion}

These findings raise doubts about the practicality of the recommendation of the WHO Study Group ${ }^{4}$ that, where possible, MDT should be continued up to bacterial negativity, namely, up to the time when the last granular bacillus has disappeared from follow-up skin smears, for this may necessitate continuing treatment for 10 years or longer. After all, removing dead bacilli from the tissues is not a function of chemotherapy but is a function of macrophages, and macrophages are peculiarly ineffective at this task in LL. It is hoped that these findings will help in providing an answer to the question of how long MDT should be continued in multibacillary leprosy. It would seem unnecessary to continue up to bacterial negativity, and justifiable to stop treatment at a stage when only granular bacilli are still present in skin smears, so long as clinical improvement is 
satisfactory. On the question of whether to stop MDT if 'solids' are present in finger smears, it seems justifiable to stop if: 1 , their numbers are small; 2 , they have been present over the previous 12 months, i.e. they are not a new discovery; and 3, they are not increasing in number. The important proviso is that at least six postMDT follow-up smears must be taken every 3-6 months for several years to make sure that they are not becoming more numerous.

\section{Acknowledgments}

I wish to thank Professor E Freerksen for permission to report on his patients, Drs E Bonnici and G Depasquale for their cooperation and assistance, and Dr Marian Ridley for reporting on skin smears.

\section{References}

1 Jopling WH, Ridley Marian, Bonnici E, Depasquale G. A follow-up investigation of the MaltaProject. Lepr Rev, 1984; 55: 247-253.

2 Freerksen E, Rosenfeld M. Leprosy eradication project of Malta. Chemotherapy, 1977; 23: 356386.

${ }^{3}$ Huikeshoven H, de Wit M, Soeters A, Landheer JE, Leiker DL. ELISA inhibition technique for the demonstration of sulphones in body fluids. Lepr Rev, 1981; 52: 11-18.

${ }^{4}$ WHO Study Group. Chemotherapy of Leprosy for Control Programmes. Technical Report Series No. 657, 1982. 